\title{
TOWARDS A DEFINITION OF PHILOSOPHICAL COUNSELLING IN SOUTH AFRICA
}

\author{
by \\ DIRK JACOBUS LOUW \\ submitted in part fulfilment of the requirements for the degree of \\ MASTER OF ARTS IN CLINICAL PSYCHOLOGY \\ at the \\ UNIVERSITY OF SOUTH AFRICA \\ SUPERVISOR: PROF D P FOURIE
}

JUNE 2009 


\section{ACKNOWLEDGMENTS}

I would like to thank the following people sincerely:

Prof David Fourie for the professional and committed way in which you have supervised this study.

My trainers at the Department of Psychology of UNISA for your quality training.

The three participants in this study for their time and effort. Without you this study would not have been possible.

My family, especially my wife, Elzette, for your continued encouragement.

My friends for your support and interest.

My fellow trainees for your camaraderie and assistance. 


\begin{abstract}
The purpose of this study was to define Philosophical Counselling (PC) or, more specifically, PC as practised in South Africa. This was done through allowing South African philosophical counsellors to tell their stories about PC. The epistemological framework was that of social constructionism. The study involved a series of in-depth interviews with three South African philosophical counsellors. The major themes that emerged from the participants' stories seemed to centre around: the existential need for the other; the conceptual need for the other; engaging with the other methodically; and caring for the other. While their stories largely resonate with current and overwhelmingly European and North American conceptions of PC, they also seem to provide a uniquely South African impetus to revise these conceptions. Moreover, the findings of this study may facilitate a dialogue between philosophical counsellors and their colleagues in related professions, especially psychotherapists.
\end{abstract}

Key terms:

Philosophical practice, philosophical counselling, philosophy and psychotherapy, philosophy, counselling, psychotherapy, the other, Socrates, Levinas, Ubuntu, South Africa, Africa, NorthSouth debate, Western and African context, social constructionism, qualitative research, hermeneutics, stories. 


\section{TABLE OF CONTENTS}

1. Introduction

2. Attempts to define PC: A literature survey

2.1 Practical versus theoretical definitions

2.2 Monistic versus pluralistic definitions

2.3 Substantive versus antinomous definitions

$\begin{array}{ll}\text { 3. Research design } & 10\end{array}$

$\begin{array}{ll}3.1 \text { Research paradigm } & 10\end{array}$

$\begin{array}{ll}3.2 \text { Sampling and selection } & 11\end{array}$

3.3 Data collection $\quad 12$

$\begin{array}{ll}\text { 3.4 Data analysis } & 13\end{array}$

4. Results: emerging themes $\quad 15$

4.1 Theme (A): The existential need for the other 15

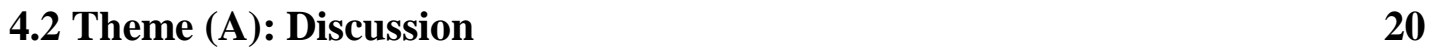

4.3 Theme (B): The conceptual need for the other 21

4.4 Theme (B): Discussion 25

4.5 Theme (C): Engaging with the other methodically 26

4.6 Theme (C): Discussion $\quad 29$

4.7 Theme (D): Caring for the other 31

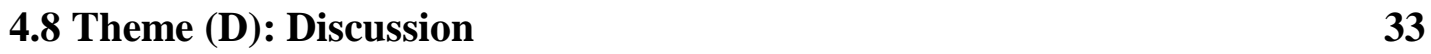

5. Towards a conclusion $\quad 34$

$\begin{array}{ll}\text { References } & 38\end{array}$ 


\section{Introduction}

Within the Western philosophical tradition the role of the philosopher as counsellor can be traced back at least as far as Socrates's (470-399 B.C.) notion of the philosopher as a 'midwife' who assists others in giving birth to their own ideas (i.e think through their problems) (LeBon, 2001). This notion was testimony to a Greco-Roman Zeitgeist that encouraged the application of philosophy to everyday problems, as could be found in the variety of suggestions of how life should be lived by, amongst others, the Pythagoreans, the Cynics, the Stoics, the Epicureans, and the Cyrenaic school of philosophy. In recent times the title 'philosophical counsellor' has been used more and more frequently since roughly the early nineteen-eighties when the German philosopher Gerd Achenbach put up a 'Philosophical Counselling' (henceforth 'PC') practice in 1981 and founded the Gesellschaft für Philosophische Praxis in 1982 (Lahav \& Tillmanns, 1995). Since then the idea and practice of PC spread to a number of other countries including the U.S.A., the U.K., The Netherlands, Austria, Switzerland, Norway, Italy, Spain, Canada, Israel, Turkey and South Africa (all, notably 'First World' or 'Northern' countries with the exception of Turkey (perhaps) and South Africa).

But what exactly is PC? Up to date relatively few publications addressed this question. Even less was said specifically about PC in South Africa. This situation is being exacerbated by the fact that many of those who debate the nature of PC do not in fact practice it (Louw, 2001). Their definitions of PC are therefore necessarily a priori, that is not based on any practical experience thereof. Moreover, because of the greater prominence that the publications of their 'First World' colleagues enjoy, the contributions of South African philosophical counsellors are easily overlooked - hence their often expressed need and efforts to have their voices heard in this regard (cf., for example, Douglas, 2005, 2008; D. Louw, 2004; T. Louw, 1999; Sivil, 2009; Van der Merwe, 2001).

The present study serves as a response to this state of affairs. As such its aim is threefold: 
- To explore and describe the experiences and conceptions of PC of philosophical counsellors practicing in South Africa (thus giving them a voice, that is, an opportunity to tell the PC story from their viewpoint).

- To derive a definition of PC and, specifically of PC as practised in South Africa from this description.

- To establish whether a uniquely South African brand of PC exists, that is, to identify peculiarities, if any, in the PC stories of South African philosophical counsellors. This will be done through a qualitative analysis (see 3.1 to 3.4 below) and against the background of current non-South African attempts to define PC.

\section{Attempts to define PC: A literature survey}

The wide variety of attempts to define PC could be summarised in terms of three overlapping sets of opposites: practical versus theoretical definitions; monistic versus pluralistic definitions; and substantive versus antinomous definitions.

\subsection{Practical versus theoretical definitions}

The word 'practical' here means 'hands-on' or 'concrete'. 'Practical' definitions of PC hence include descriptive accounts of its actual practice. Prins-Bakker's (1995) description of her application of philosophical skills in marriage counselling and Marinoff's (2000) description of his five stage approach may serve as examples.

Prins-Bakker's (1995) marriage counselling comprises six stadia: (a) clients are asked to give a first description of the problem in their marriage; (b) clients analyse their respective personalities or identities in view of the question, 'Who am I?'; (c) clients reflect on their lives in terms of questions like, 'What do I expect from life?', and, importantly, 'Is this consistent with how I

actually live?'; (d) clients reflect on the concept 'phase of life' and on their past and current 'phase(s) of life'; (e) clients individually reflect on their relationship in terms of questions like, 
'What would it mean to be happily married to you?'; and (f) clients reflect on the same question as a couple, thus gaining a combined perspective on a 'successful marriage'. According to PrinsBakker (1995), these stadia require a number of overlapping skills from both counsellor and clients, among which the skills involved in making the other feel attended to; being a partner in dialogue, yet also a critical observer; objective assessment; conceptualization, critical examination, and creative imagination; and the ability to analyse and synthesize.

Marinoff (2000) describes PC not in terms of six stages, but five. He calls it the "'PEACE' process: problem, emotion, analysis, contemplation, equilibrium” (Marinoff, 2000, p. 38). In the first two stages the problem and the emotional reactions that it triggers are identified. These emotions must be experienced authentically and expressed beneficially. For Marinoff (2000) “most psychology and psychiatry never progress beyond this stage” (pp. 38-39) (much more about PC vis-à-vis psychology and psychiatry later - see 2.3 below). In the third stage options for addressing the problem are listed and weighed. In the fourth stage the client obtains a “philosophical disposition” through exploring, with the counsellor, the philosophical framework within which what transpired in the first three stages would make sense to the client. This then leads to the fifth stage in which the client reaches equilibrium, that is, "understands the essence of [his/her] problem and are ready to take appropriate and justifiable action” (Marinoff, 2000, pp. 39-40). As such, the whole process involves a variety of skills like empathetic listening, objectification (i.e. taking a step back), logical reasoning, conceptual analysis, critical and creative thinking, synthesizing a variety of particulars, and seeing things in perspective.

In contrast, Prins-Bakker's (1995) and Marinoff's (2000) definitions of PC may be distinguished from 'theoretical' definitions thereof. 'Theoretical definitions' here means any definition of PC that excludes a description of its actual practice. Wikipedia (http://www.wikipedia.org/), for example, describes PC as “...a relatively new movement in philosophy which applies philosophical thinking and debating to the resolution of a person's problem”, adding that it was proposed as “...an alternative to psychotherapeutic culture [and medicalization]...”, and that it “...frequently involves a rethinking of values and beliefs and is also a method for the rational resolution of conflicts” (Philosophical Consultancy, n.d., para. 1-3). The Canadian Society for Philosophical Practice (CSPP) (http://www.philosophicalpractice.ca/), again, ‘unofficially’ 
quotes a board member's statement on PC, according to which PC comprises of a "dialogue with a professional philosopher”. It may address, from an array of historical and contemporary angles, such "concrete” problems as troubled relationships, the experience of illness, moral dilemmas, confidence problems, professional crises, anxiety, depression, despair or “...foundational questions about the meaning of life, God, freedom, [and] death”. As such, PC is based on the ancient belief that “...personal problems are of a philosophical nature...”. It does not operate via diagnoses and treatments, but is nevertheless therapeutic in that it “...enliven (sic) and empower a person” (Von Morstein, n.d., para. 1-2, 8), hence supplementing - though not substituting psychotherapy or psychiatry.

\subsection{Monistic versus pluralistic definitions}

'Monistic definitions' refers to definitions of PC that defines it in terms of the work of one specific philosopher or approach in philosophy. In so far as the latter is concerned, Lahav's “principle of worldview interpretation” (1995, p. 4) springs to mind. According to him this principle constitutes the most fundamental element of PC. As such, it is an essential element in all PC approaches. It is what makes these approaches philosophical. "Worldview interpretation" seems to imply three roles that the philosophical counsellor can and, according to Lahav, ought to play in the PC process (please note: the use, here and elsewhere, of the male or female pronoun in the abstract third person is arbitrary and does therefore not reflect sexist bias): (a) assisting the client in articulating the view of herself and the world that is being expressed by her everyday life; (b) helping her to critically examine its problematic aspects, for example inconsistencies or aspects that impairs her functioning; and (c) assisting her to change, enrich or develop her worldview where necessary. A philosopher, Lahav (1995, p. 10) claims,

is skilled in uncovering implicit presuppositions and offering alternative ones, in drawing implications, in analyzing concepts, and in exposing hidden patterns and structures. A philosopher familiar with the literature about concepts related to human life - those of freedom, the meaning of life, the right and the wrong, or the self - is acquainted with a variety of alternative lines of thought. A philosopher trained in phenomenology is also 
capable of describing aspects of subjective experience that are commonly overlooked by the average person.

Lahav's (1995) views regarding the embeddedness of worldviews in ways or forms of life is reminiscent of the views of Ludwig Wittgenstein, the philosopher in terms of whose work Ellenbogen (2006) illustrates PC 'monistically'. Wittgenstein (as cited in Ellenbogen, 2006, p. 103) seems to be the most relevant Western philosopher for this purpose since for him philosophy is therapy and "the philosopher's treatment of a question is like the treatment of an illness”. The picture of a philosophical counsellor that emanates from his work is of a therapist who treats our everyday existential problems through clearing up both our confusing use of language and our confused conceptions about the use of language, thereby - to use Wittgensteinian jargon (Ellenbogen, 2006, p.103) - "showing the fly the way out of the flybottle" through "untying the knots in our thinking". According to Ellenbogen (2006), the philosophical counsellor would not, like a psychotherapist, diagnose a client in terms of ready made generic labels, but attend to the particularities of her situation. That is, s/he would heed Wittgenstein's warning (Ellenbogen, 2006, p.106) to “not assume that each thing called X has one thing in common”. Moreover, a Wittgensteinian therapist (Ellenbogen, 2006, p.104) would encourage the client autonomously to identify and critically assess her hidden or unexamined assumptions - "the pictures that might be holding her captive" - so as to allow herself rationally to change her way of seeing things if and where necessary.

Ellenbogen's (2006) essay counts among a growing number of definitions of PC with reference to the work of one specific philosopher - though, strictly speaking, in this regard one needs to distinguish between defining PC in terms of the work of a philosopher and practising PC in similar manner. Ellenbogen's (2006) essay serves as an example of the former. So does, for example, Dias's (2006) exposition of the way in which Descartes served as a philosophical counsellor for Princess Elizabeth of Bohemia. Examples of the latter, that is, of practising PC with reference to the work of a specific philosopher, may include De Botton's (1997) application of Marcel Proust’s work, Svare’s (2006) assessment of Immanuel Kant's analyses, or Fleming's (2006) use of Chuang Tzu’s philosophy - to name just a few examples. 
'Pluralistic' definitions of PC are definitions that draw on the work of a variety of philosophers or approaches. It includes attempts to synthesize or integrate the wide and often contradicting variety of current definitions of PC. Raabe’s (2001, p. xviii) “overarching model” of PC rates as one of the most prominent in this category. It is based on a comprehensive survey of both theoretical conceptions of PC and descriptions of practice, that is his own practice and the practice of a number of other philosophical counsellors. Raabe (2001) thus draws on a bewildering variety of not only philosophers, but also (albeit often indirectly) psychologists. According to his model, PC consists of “four stages” (Raabe, 2001, pp. 125-166). The first is a "free floating" stage that constitutes the building of a rapport between counsellor and client: the counsellor familiarises himself with his client and her concerns, while assessing whether PC would be the appropriate response. The client, likewise, becomes acquainted with the counsellor and his approach. The second stage is called "immediate problem resolution" and consists of the counsellor allowing the client to use his (i.e. the counsellor's) philosophical reasoning abilities to discover a solution to her immediate concerns (e.g. a moral dilemma, a difficult decision, prioritising, assessing a situation, etc.). At this stage the counsellor is clearly the expert, though this status is qualified by two considerations: (a) he is not providing answers, but merely guiding his client towards genuinely discovering her own solutions; and (b) the counsellor draws on the client's own world view, that is, though he applies his own well developed reasoning skills, his points of departure are the client's assumptions or beliefs. In stage three the counsellor “intentionally teaches” his client the very critical reasoning skills that he applied in stage two, thereby allowing her to proactively avoid or prevent similar problems. For Raabe (2001), it is this stage that makes PC distinctly philosophical and distinguishes it from psychotherapy. Proactive avoidance commences in stage four when the counsellor assists his client to “transcend” (Raabe, 2001, p. 158) her focus on her immediate problems and rather to apply her newly acquired critical reasoning skills to the worldview or paradigm within which these problems appear. This is the stage where the counsellor clearly abdicates as an expert, where the client self-critically and autonomously determines the adequacy of paradigms or worldviews (including her own), and where she thus reflectively gazes beyond the parameters of her current frame of reference, or, in short, where she practices 'philosophy as a way of life' (cf. Hadot, 1995). According to Raabe (2001), his four-stage method serves an end that would widely (though not universally) resonate with philosophical counsellors, namely to assist clients in the 
exploration and grounding of their worldviews through a client centred dialogue that involves description (phenomenology), interpretation (hermeneutics), and critical and creative thinking, thereby: (a) addressing the variety of clients' problems including not only conceptual issues or questions about the meaning of life, but also emotional and behavioural problems in so far as feelings, attitudes and actions are determined by thinking or reasoning; and (b) enhancing clients' self-knowledge, autonomy and the authenticity of their existence. Moreover, according to Raabe (2001, p. xxi), many philosophical counsellors would agree that his model of PC encapsulates its fundamental elements or requirements, including:

philosophical inquiry, a minimal competency on the part of the client to be able to conduct a rational inquiry, a cooperative client/counselor relationship, the ability of the counselor to adapt academic philosophy to counselling, the necessity of direct teaching, an unrestricted agenda which allows for change and progress in the client, and a clear methodology.

Knapp and Tjeltveit (2005, p. 559) who, like Raabe (2001), defined PC in view of a survey of conceptions thereof, list him as a "broad-scope philosophical counselor", that is one for whom philosophical problems also include all mental problems (e.g. depression, anxiety, strained relationships, etc.) in so far as they are not medical problems or biologically caused. "Narrowscope philosophical counselors” (Knapp \& Tjeltveit, 2005, p. 559), on the other hand, exclusively focus on issues typically outside the domain of psychotherapy, for example logical, metaphysical, ethical and political issues. Though they pay particular attention to relating concepts or ideas to the life situations of clients, narrow-scope philosophical counsellors do not purport to treat mental illness. Both broad-scope and narrow-scope philosophical counsellors follow an array of divergent approaches: directive and/or nondirective; formal (i.e. methodological) and/or informal; skills based (i.e. based on philosophical techniques) and/or theory based (i.e. based on philosophical readings). To varying degrees all these approaches involve "clarifying the philosophical issues in practical issues, defining key terms, questioning and critically analyzing presuppositions and basic principles (especially when hidden), and identifying and correcting problems in thinking (e.g., identifying and eliminating inconsistencies and contradictions)” (Knapp \& Tjeltveit, 2005, p. 559). Philosophical counsellors assist clients in identifying the different options available to them in a given situation and the range of angles 
from which it could be approached or perspectives within which it could be understood. Finally, they help clients find their own philosophical standpoints so as to substantiate their choices autonomously.

\subsection{Substantive versus antinomous definitions}

All the above definitions of PC (see 2.1 and 2.2) could be categorized as 'substantive' definitions, that is definitions that purport to say what PC is. However, PC has more often, especially during the early years of its existence, been defined antinomously, that is by saying what it is not. PC, so it is claimed, is to begin with not traditional or academic philosophy. Academic philosophy merely serves as the general theoretical edification of interested parties (usually professors and their students at an academic institution). As such, it has an intrinsic value. That is, it is deemed to be worthwhile irrespective of whether it serves some or other specific practical purpose (Gutknecht, 2006). PC, on the other hand, specifically aims to address particular real life problems of clients (Prins, 1997), though it may use the same tools and produce the same knowledge as academic philosophy (Paden, 1998). While academic philosophy often appears as "mental gymnastics having nothing to do with life” (Marinoff, 2000, p.8), the philosophical counsellor draws on philosophy as “a mode of existing-in-the-world” (Hadot, 1995, p. 265) to suggest “practical knowledge” (Schuster, 1998, p. 48) to counselees.

Yet, in spite of its practical nature it would, for some authors, nevertheless be misleading simply to equate PC with so-called 'applied philosophy'. For them, not all professionals who 'apply' philosophy may rightly be called 'philosophical counsellors'. Unlike philosophical counsellors, some professionals apply philosophy merely in an advisory capacity, for example a consultant on an ethics board. As such, s/he objectively deals with theoretical issues, not with the personal problems of an actual individual (Van der Merwe, 2001). These consultants qualify as 'philosophical practitioners', though not as 'philosophical counsellors' (Shipley \& Leal, 2002). PC constitutes "an actual conversation with an actual person” (Schuster, 1999, p. 33; cf. also Schuster, 1997a, 2002). It does not include the relatively disengaged application of philosophy in groups. Thus, as Marinoff (2000, p. 13) summarises: 
The term philosophical practice refers to three types of professional activities: counseling individual clients, facilitating various kinds of groups, and consulting to various kinds of organizations. Hence a philosophical counselor is one type of philosophical practitioner (italics in original).

For a number of authors, though, PC also refers to working with groups and not just individual counselling (cf. Raabe, 2001). These groups are thought to include not only corporate meetings or formal organizational gatherings, but also relatively informal 'philosophical cafe's' (cf. Phillips, 2001). It may also include groups of children in an educational setting, as for the philosopher who practices ‘Philosophy for Children’ (cf. Lipman, 1988). But perhaps the most popular version of PC in group format goes under the name of 'Socratic Dialogue'. This entails more than and even contradicts the well-known 'Socratic Approach' in which the counsellorcum-midwife allows the client to give birth to his/her own ideas - a decidedly unstructured and unpredictable process. The 'Socratic Approach' is especially popular amongst those who advocate that PC does not and should not have any specific method (cf. Achenbach, 1995). 'Socratic Dialogue', though, is exactly that: a method with strict rules of procedure. As facilitator, the philosophical counsellor puts a question to the group. Participants then need to submit concrete examples of situations in which they encountered the problem in the question. The facilitator subsequently decides on one example to serve as the focus of the discussion. The aim is for all the participants to agree on an appropriate answer to the question (excluding the facilitator; s/he remains, in this sense, disengaged) (Kessels, 1997).

But, whether PC is thought to include group work or not, proponents of PC devoted by far the most of their time and energy to the distinction between PC and psychotherapy (Schuster, 1999; Segal, 1995). The psychotherapist, so we are told by some, works with a specific theory and method in terms of which s/he readily identifies or diagnoses the symptomatic behaviour of his/her patients, and in terms of which s/he then tries to cure or normalise him/her (Mijuskovic, 1995). The philosophical counsellor, on the other hand, is (a) not equipped with a specific method, theory or ready-made answers, and (b) nor does s/he try to cure or normalise his/her client. Through dialogue with clients philosophical counsellors rather concentrate on the analysis and innovation of concepts, on interpretations and on trains of thought or reasoning. Healing 
might follow as a by-product of this process, but it does not constitute its main aim. PC is an open-ended inquiry in which the philosophical counsellor facilitates the "self-diagnosis" (Schuster, 1998, p. 38) of his/her client, that is, the philosophical counsellor continually cocreates, with the client, a space within which the latter could clarify his/her thoughts (Achenbach, 1995). This understanding of the differences between PC and psychotherapy further implies: (c) that the 'therapist-patient' hierarchy of psychotherapy does not obtain in PC and that the philosophical counsellor can therefore not impose his/her idea of illness or wellness on a passive patient (Prins-Bakker, 1995); (d) that PC does not involve the psychotherapeutic manipulation of clients through behavioural techniques or medication and that those who may need such treatment (e.g. psychotic patients) do therefore not qualify as candidates for PC (Marinoff, 1998). PC is "therapy for the sane” (Marinoff, 2000, p. 11); and (e) that PC does not involve the empirical detection of hidden psychological causes or processes, but the analysis or interpretation of people's conceptions of themselves and their world through "pure (nonempirically based) thinking” (Lahav, 1995, p. 12; cf. also Lahav, 1996). That these distinctions between PC and psychotherapy are based on a reductionist or, at best, confused understanding of psychotherapy almost goes without saying. To be sure, many proponents of PC realize this (among whom South African proponents, as the present 'qualitative analysis' showed - see below). Yet, in their fervour to find a niche for their newly found profession, some of them could not resist the temptation to make straw men of their perceived opponents.

\section{Research design}

\subsection{Research paradigm}

The paradigm within which this study was conducted can be described as postmodern, social constructionist and qualitative. It was postmodern in the sense that it denied the 'monistic thesis' of modernist epistemology, namely that there could only be one legitimate or 'true' understanding of reality (Louw, 1996). This study rather celebrated the fact that people 'create’ a multitude of realities through varied interpretations of their experiences, that is, through the variety of stories that they tell about reality as experienced by them. However, these realities are not being created in isolation, but in dialogue with one's culture, community or social 
environment. This assumption lies at the heart of social constructionism (Fourie, 1996). Moreover, the postmodern, social constructionist researcher is particularly critical of stories that suppress otherness, that is, that override the particular stories of others (Doan, 1997). For the purposes of this study, this meant that there was no effort to define PC through a simple description of a reality that was assumed to exist independently from people's interpretations thereof. On the contrary, the focus in this study was precisely on these interpretations specifically the interpretations of the South African philosophical counsellors who participated in this study (henceforth 'the participants'). Moreover, the researcher was wary of allowing his own understanding of PC (i.e. the understanding of PC that he had brought to this project) to obscure the participants' particular conceptions thereof. More specifically, this study embodies the researcher's story of the participants' stories of PC in dialogue with them. After all, the purpose of this study included creating a space in which the participants' own particular voices could be heard. As such, the research design used in this study reflected a qualitative approach. It was qualitative in that the researcher sought to investigate a phenomenon using rich, detailed narrations of participants, rather than quantifications, thus gaining insight into the complex and concrete 'real life' experiences of particular individuals, rather than the exact verification or falsification of hypotheses in a controlled (and, in this sense, 'abstract') environment (Liamputtong \& Ezzy, 2005).

\subsection{Sampling and selection}

Sampling was purposive and convenience selection was used. Participants who could supply detailed descriptions of the subject under study (viz. PC or more specifically PC as practised in South Africa) were selected. The names of potential participants were obtained from the membership list of the South African Philosopher Consultants Association (SAPCA). In order to be selected at least the following had to apply to a potential participant:

- S/he had to practice as a counsellor in South Africa.

- S/he had to refer to him-/herself as a 'philosophical counsellor' and describe his/her practice as 'PC'. 
The sample consisted of two males and one female: Peter, Mary, and Tsobe (pseudonyms).

Peter is 49 years old and has been running a PC practice in the Eastern Cape Province of South Africa for the past five years. He received training in PC and the facilitation of Socratic Dialogue at the Dutch Society for Philosophical Practice (VFP). He also participated in workshops of the South African Philosopher Consultants Association (SAPCA), of which he is a founder member. Until recently he was also a member of the British Society of Consultant Philosophers (SCP). His highest academic qualification is a doctoral degree in philosophy.

Mary is 51 years old and has been running a PC practice in the Western Cape Province of South Africa for the past seven years. She is a member of the South African Philosopher Consultants Association (SAPCA), but never received any formal training in PC. However, she participated in the activities of the American Society for Philosophy, Counseling and Psychotherapy (ASPCP) and recently acted as the guest editor of a special edition on PC of a prominent academic journal. Her highest academic qualification is a master’s degree in philosophy.

Tsobe is 57 years old and has been running a PC practice in the Gauteng Province of South Africa for the past 12 years. Like Peter, he is a founder member of the South African Philosopher Consultants Association (SAPCA) and he participated in its workshops, though he is not a member of any other PC society. His highest academic qualification is a doctoral degree in philosophy.

\subsection{Data collection}

The unstructured interview was used as the method to obtain information. Interviews were of a written format and were conducted over the internet with each participant separately. As many interviews were conducted as were necessary for the participants to tell their PC stories. Three interviews were conducted with Peter, two with Mary, and two with Tsobe. The interviews commenced after the purpose and procedures of the study were explained and the following was obtained from each participant in written format: (a) personal data, and (b) consent to use information shared during an interview. The researcher initiated each interview with the 
question: 'Please describe your experience(s) of PC'. Participants were given the opportunity to respond comprehensively to this request, after which follow-up questions were posed by both the researcher and participants. Participants could not see each other's responses. Questions posed by the researcher were mostly open-ended and exploratory, yet focussed on the central theme of the particular participant's experience(s) of PC. As such, interviews constituted the co-creation of spaces within which participants’ own voices could be heard. Moreover, both researcher and participants refined their respective understandings of PC as interviews progressed. Through speaking we found our own voices.

The participants' contributions or stories were necessarily recounted through the researcher's eyes. The import of these stories for an understanding of PC (and, specifically, of PC as practised in South Africa) therefore says as much about the researcher as it does about the participants. Nevertheless, reflecting the participants' stories as accurately as possible remained an important ideal throughout the process. This required self-reflection, which, for the researcher, meant reflecting on the potential influence on this study of the fact that he taught philosophy for a number of years, practised clinical psychology under supervision, and has a long standing interest and involvement in the PC movement. It included liaisons with members of the Dutch Society for Philosophical Practice (VFP), American Philosophical Practitioners Association (APPA), and the American Society for Philosophy, Counseling and Psychotherapy (ASPCP), and co-founding the South African Philosopher Consultants Association (SAPCA). However, the researcher never practiced PC formally or extensively.

\subsection{Data analysis}

The method of analysis applied in this study was a hermeneutic thematic analysis. That is, the researcher engaged with the participants' contributions in a process of interpretation in the hope that it would reveal “...a coherent clustering or ordering of themes of experience...” (Kelly, 1999, p. 407). The following steps were followed (as adapted from suggestions in this regard by Kelly (1999), Kvale (1983), and Liamputtong and Ezzy (2005)): 
(a) Familiarisation and immersion: The researcher read the contributions of participants several times so as to become intimately familiar with the contents thereof. He, as it were, immersed himself empathetically in the contributions. This was done in-between interviews and again after all the interviews were conducted.

(b) Thematising: Themes underlying the participants' contributions were inferred in view of regularities or patterns.

(c) Coding: Words, phrases or sections that are thematically related (i.e. that are instances of a particular theme) were grouped together.

(d) Elaboration: The researcher obtained a deeper or richer understanding of inferred themes (see 'Thematising' above) through further critical analysis thereof within the context of the contribution in question as a whole. This process constituted a so-called 'hermeneutical spiral': moving back and forth in cycles between the parts of a contribution and the contribution as a whole. A deeper understanding of themes was also gained through discussing them with other interested parties (e.g. colleagues, supervisors, etc.). Participants in this discussion had to be aware of the influence that their horizons of understanding (i.e. their values, assumptions and interpretations) had on their contributions. This, of course, also applied to the researcher, as was acknowledged in the final step (see 'Interpretation and checking' below).

(e) Interpretation and checking: The researcher documented his final account or interpretation of the contributions of participants - that is his story of their stories - in terms of identified themes. He also and again 'checked' or reflected on his role in the whole process. 


\section{Results: emerging themes}

The following themes emerged from the participants' contributions. As such they constitute the researcher's story of the participants' stories.

\subsection{Theme (A): The existential need for the other}

Seeking the acknowledgment of others through dialogue seems to characterize the participants' overall experience of being a philosophical counsellor.

Peter seems to need others to acknowledge him both as a private individual and as a professional philosophical counsellor (more about the latter acknowledgment later). From the outset it becomes apparent that he does not wish to engage in PC, or in reflections about his engagement in PC, as an anonymous party, but as a private (i.e. a specific, identifiable or 'name-carrying') individual. He therefore commences his dialogue with the researcher regarding his “...engagement with and experience of PC...” by introducing himself as follows: "I am...[full name]..., an adult male in my forties who lectured philosophy at the University of ... in the Eastern Cape for the past 22 years. During my student years I was impressed by the range, depth and practical relevance of philosophy as a classical discipline, but also by the tried and trusted attitude of critically and self-critically investigating truth, knowledge, values, beauty, significance and meaning”. Notice just how detailed the acknowledgment is that Peter seems to require from the researcher with regard to his personal or biographical particulars. To begin with, he seems to give his consent to, or even instruct the researcher to address him by his full name. He does this with full knowledge of the fact that he agreed with the researcher to remain anonymous. This may be significant for a number of reasons. By stating his full name in spite of the said agreement, Peter may want to provide a guarantee of the authenticity of the thoughts that he is about to share with the researcher. That is, he may want to reassure the researcher that these thoughts are his and that they are sincere. He may also want to illustrate that in some sense or on some level the use of his name overrides any previous agreement not to do so. For instance, he may want to illustrate that the actual interlocution with the researcher in the here and now allows

for or requires the use of his name, even if he expects of the researcher not to do so when he 
reflects on it at a later stage. And by doing so, the participant may want to establish an (for him) important hierarchy: his actual interlocution with the researcher in the here and now is more important than the researcher's reflections on it at a later stage. Why would Peter want to establish such a hierarchy? Perhaps because he is, as a scholar of "recent philosophical hermeneutics”, all too aware of the alienating meanings (that is, alienating for the 'original' author) that a text may acquire through the interpretive eyes of others (in this case, the eyes of the researcher). It is as if the participant wants to distance himself from, and hence protect himself against, these meanings through establishing the said hierarchy. But, in the third instance, by stating his full name, Peter may also be engaging in an interactional strategy often followed by clients and/or therapists in counselling, namely the so-called 'double bind' (Swart \& Wiehahn, 1979). By stating his full name, after having agreed with the researcher that he would remain anonymous, Peter seems to instruct the researcher to both use and not use his name. The researcher is damned if he uses the participant's name and damned if he does not. Why would Peter want to put the researcher in a double bind? A double bind immobilizes the recipient, making him uncertain and consequently dependent on the sender. Thus, by putting the researcher in a double bind, Peter seemingly tries to take control of the interaction or dialogue between himself and the researcher and, hence, of the meaning that is being and will be ascribed to his thoughts regarding his “engagement with and experience of philosophical counselling”. Here, again, we may be witnessing a manifestation of 'hermeneutical anxiety' on the part of Peter, that is an effort to safeguard the 'original' meaning of his thoughts on PC, borne from a fear that it may be hijacked by the researcher. This understanding of Peter's actions vis-à-vis the researcher also implies that, at least to an extent, he regards the sharing of his thoughts on PC with the researcher as itself an exercise in PC.

But, as indicated above, his full name is not the only personal or biographical particularity that Peter hopes to have acknowledged through his dialogue with the researcher. According to his introduction of himself, Peter also needs to have a variety of other personal or biographical particularities acknowledged, including his developmental stage in life (“adult”), his gender (“male”), his age (“forties”), his vocation (a philosophy lecturer), his geographical location ("University of... in the Eastern Cape"), his history (he has been a philosophy lecturer for the past 22 years; also note the reference to his student years), what motivates/inspires/impresses 
him ("the range, depth and practical relevance of philosophy as a classical discipline"), and his quest to "critically and self-critically” investigate "truth, knowledge, values, beauty, significance and meaning”. All these biographical particularities resonate well with the "phenomenologicalexistentialist model” to which Peter refers (in spite of the fact that he, ironically, views "recent philosophical hermeneutics" as a viable alternative for this model). According to the existentialist understanding of human nature (Corey, 2001), the basic dimensions of the human condition inter alia include: (1) the capacity for self-awareness (cf. Peter's identification of all the above-mentioned particularities bears witness to this capacity); (2) the freedom of the individual to make him-/herself through the choices that s/he makes within the confines of a specific, given situatedness (cf. the fact that Peter is a philosophy lecturer is the result of a choice that he made; the same applies - albeit perhaps to a lesser extent - to the fact that he has been a philosophy lecturer for the past 22 years and that he has held this position at a specific university; the fact that the participant is an adult male in his forties has relatively little to do with the choices that he made - these variables rather belong to the 'given situatedness' of which the existentialist model speaks); (3) meaning in life or the lack thereof (cf. the former seems to apply to Peter: he seems to be inspired by philosophy as a classical discipline); and (4) the search for goals, values, and a purpose (cf. Peter's quest to “critically and self-critically” investigate “truth, knowledge, values, beauty, significance and meaning”).

However, apart from efforts to gain acknowledgement as a private individual through dialogue, Peter's experience of being a philosophical counsellor also seems to be characterized by efforts to gain acknowledgment as a professional counsellor through the same means. The dialogue in question was and is with a variety of both international colleagues and fellow South Africans. In January 1999 he, for example, attended a PC training course in Oxford where he liaised with philosophical counsellors, including trainees and "experienced counsellors" from England, The Netherlands, Luxembourg, Turkey, Scotland, Wales and South Africa. In the same month Peter presented a paper on PC at the annual congress of the Philosophical Society of Southern Africa (PSSA) and subsequently founded, with a few South African colleagues, the South African Philosopher Consultants Association (SAPCA) in 2000. In April 1999 he toured Europe and Britain extensively during which he presented a paper at the International Congress for Philosophical Practices. And in May 1999 he again received training in the practice of 
philosophy, (or, more specifically, in the "facilitation of Socratic Dialogue”) in Belgium from Dutch philosophical counsellors belonging to the Dutch Society for Philosophical Practice (VFP).

Like Peter, Mary also seems to need others to acknowledge her both as a professional philosophical counsellor and a specific, identifiable, concrete, critical and self-critical individual with an age, gender, vocation, location, a quest and a cause. Her contribution includes a reference to two web sites where all the ingredients of this 'detailed acknowledgment' can be found. What was said about Peter in this regard thus seems to apply mutatis mutandis to Mary. However, unlike Peter, Mary leaves it up to the researcher whether or not to use her real name. "You may as well use my name,” Mary says, “it’s not like it won't be obvious who I am, to anyone who might care - and I could always use the publicity!” Therefore, to the extent that the foregoing relates to Peter's decision unilaterally to overrule his anonymity, it does not apply to Mary. (For the sake of consistency, the researcher decided to use a pseudonym for Mary in any event).

But, be that as it may, for Mary - following the philosopher, Emmanuel Levinas - there is also a more fundamental sense in which her experience of being a philosophical counsellor involves the need for the 'acknowledgment of others' (so to speak). As an "I”, so Mary argues, she is always and already intimately related to the need or "question" of "the Other”. In fact, her very existence as a "self" or "unique subjectivity" depends on this relationship. The "I" only exists as “response” to the need or "question” of “the Other”. “As I am compelled to [the Other], as I am interrogated by a question,” Mary says, “so I am...it is as if one were questioned into being...and my philosophical practice, before anything I say, is already an expression of response, for the Other”. Mary is not merely alluding to non-verbal communication here. On the contrary, for her "the first thing that a Levinasian counsellor knows," is that, at bottom, this "dialogue” with the Other transpires pre-reflectively or "prior to knowledge”. It constitutes an “earlier” (i.e. prereflective) “engagement with alterity” which serves as a precondition for PC. Or, as Mary also puts it: “Philosophical counselling as a philosophical practice doesn’t begin with knowledge and applications, but with a state or condition or experience that can be thought of - if you will - as having a guest” (italics in original). This is the first sense in which Mary regards a need for 
others (read: the Other) as part and parcel of (read: fundamental to) PC. The second sense becomes apparent on a reflective level, that is, when the counsellor "starts to speak", when she addresses the question of her "guest" - who, on this level, is encountered not as "the transcendent Other”, but as "an other”, that is a "particular person of qualities and history”. For Mary, philosophizing, and thus PC, involves “...a movement to dialogue...to conversation - a yearning to consort and take refuge with others". "Every word” of the counsellor, she says, “anticipates” the client, “...who might recognize what I am describing...who might see the same thing”. In fact, the very act of speaking involves this "yearning”. Or, as she puts it: “...my speaking requires a you who hears” (italics in original). Thus understood, the question addressed in PC constitutes a need of both client and counsellor, or, in the words of Mary (quoting Levinas), it is really a question "between us": the counsellor's response to the client's question or need is at once “...an appeal for help, for aid addressed to another”. For Mary, caring for or "working on the self” therefore has a dual purpose in PC: (a) to effectively assist the other, that is (in Levinasian terms), not to "crush the other"; but also, importantly, (b) to ensure the assistance of the other, or, more precisely, to safeguard the "vulnerable self" against the inattention of the other, against being “crushed by the other”.

Tsobe's contribution, like the contributions of both Peter and Mary, seems to indicate a need to be acknowledged both as a private individual and as a professional - and this acknowledgment needs to be similarly 'detailed' (his contribution includes the title of one of his books in which all the detail in question can be found - cf. Mary's reference to web sites). Moreover, by providing the title of his book, Tsobe, like Peter (but unlike Mary) unilaterally albeit indirectly overrules his agreement with the researcher to remain anonymous. What was therefore said about Peter in this regard seems to apply mutatis mutandis to Tsobe. That is, the realization that the acknowledgement in question can only be obtained through dialogue, seems to have sparked a similar anxiety in Tsobe: the angst of trusting one's interlocutor not to hijack one's identity, whether as a professional or an individual, through alienating interpretations thereof. However, for Tsobe, as for Mary, the experience of being a philosophical counsellor also involves a need to be acknowledged in a more fundamental sense. For him, PC fundamentally entails a need for the other in so far as it embodies the "ancient African world view" of Ubuntu. In terms of this world view "a person is a person through other persons”, or, as Tsobe also and significantly puts it: " $I$ 
am a person through other persons" (italics added). Being an "I" by definition means "beingwith/through-others”, that is, I only exist in my relationship with the other. Tsobe's experience of PC thus leaves no room for the Western or Cartesian conception of the solitary individual that may, as such, meaningfully exist in and of himself. Within the Ubuntu world view, neither counsellor nor client (or "visitor” to use Tsobe’s term) could be human independently of the other. "Ubuntu is the quality of being human," says Tsobe, “and being human means being human through other human beings”. This interdependence also and derivatively applies to the counsellor as counsellor, and the visitor as visitor. Just as “a king is a king through his followers, and a manager is a manager through his colleagues," claims Tsobe, the counsellor is a counsellor through his visitors, that is, the counsellor only exists as counsellor if acknowledged as such by his visitors. Or, as he also puts it, the counsellor may pose questions, but his "questioning requires a response”. Conversely, the visitor would, on her part, not exist as visitor if not acknowledged as such by the counsellor. Ubuntu unites counsellor and visitor "reciprocally": “caring for [i.e. acknowledging] others by implication means caring for [i.e. acknowledging] yourself”.

\subsection{Theme (A): Discussion}

It is as if, by participating in this research project, the participants were reminded of the fact that

the process of PC, by the nature of the case, assumes the presence of a counsellor, that is, of an 'I'. Philosophy in PC is “philosophy in the first person” (Màdera \& Tarca, 2008, p. 166). More specifically, they discovered that the counsellor, like any other human being, has needs and wants which, if left unattended, would seriously undermine the counselling process. The philosophical counsellor, as counsellor, needs counselling. Participants hence emphasized 'care for the self' not only with regard to the counselee, but also to the counsellor. This emphasis echoes Lahav (2006) who warns that, in their eagerness to focus on the problems of others, philosophical counsellors tend to neglect themselves. PC, he claims, “...must deal primarily with the [counsellor's] own life, not with the lives of clients...who among us... has already attained wisdom, so that he can now allow himself to focus only on the lives of others? If I wish to be a philosophical [counsellor], then my own life is at issue...” (Lahav, 2006, p. 95). For this reason, Lahav has in fact substituted PC for what he calls "Grand Philosophical Practice”, that is, "a way 
of life, a personal journey in which the practitioner seeks to understand and live life philosophically, in the companionship of fellow philosophical seekers” (2006, p.95; cf. also Robbins, 2006). As explained, for participants self-knowledge (including knowledge of their 'vulnerability' or 'dependency') came through their encounter with others, including the researcher and their clients. Their dialogic interaction with others called them to themselves, to put it in Jopling's (2000) parlance. This process was well noted by Norman (1995, p.53) whose "ecological" notion of the "interdependence" of counsellor and counselee includes the imperative to “...hear messages...different...to one’s own, to recognize 'the power of strangeness' which will 'take us out of our old selves' and 'aid us in becoming new beings'”. Thus understood, the 'vulnerability' of the counsellor in the face of the counselee is, paradoxically, a strength in at least three senses: (a) interaction with the counselee creates a space for creative self-realization (Van Hooft, 2002); (b) the counsellor's needs and wants, revealed to him/her through the presence of the counselee as a challenge to be for the other, empowers him/her successfully to meet this challenge, that is, the counsellor “...learns to heal through his or her own woundedness...” (Lifschitz \& Oosthuizen, 2001, p.127); and (c) as such, the counsellor may come to see him-/herself as “...a kind of human 'instrument' by which others are helped to deal with their particular life issues...” (Walsh, 2005, p. 505).

\subsection{Theme (B): The conceptual need for the other}

Peter developed - and is developing (“The experience of philosophical practice,” he says, "is an interesting process which still unfolds itself and develops as a personal learning experience”) his conception of PC through comparing it with other counselling practices that also involve the application of philosophy. These include inter alia "the Socratic facilitation of dialogue, philosophy with children, dilemma training, and philosophy with organisations”. It also includes the "Café Philo" where people discuss any philosophical topic "in a relaxed and non-direct environment (e.g. a restaurant)”. In all these instances the philosophical counsellor works with groups, while PC involves a “one-to-one relationship between counsellor and client”. Peter therefore prefers to refer to philosophers who work with groups as "consultants" and not “counsellors”. However, he also defines PC by comparing it to psychotherapy or what he also calls “therapy in psychology”. In fact, his reflections on PC were originally triggered by a friend, 
a clinical psychologist “...who became more and more aware of the limitations of his own practice and specifically requested 'philosophical counselling'”. Their discussions over a period of about three years provided the context within which a variety of dissimilarities and similarities between PC and psychotherapy became apparent for him. The psychotherapist, to begin with, sees her customer as a "patient”, while the philosophical counsellor regards him as a "client” or "partner in dialogue”. This seems to be a major dissimilarity for Peter. He says: "There is a world of difference between the extremes of a patient on the one hand, and a partner in dialogue on the other”. Moreover, the philosophical counsellor is more skilled at handling moral concepts than the psychological counsellor. "The psychologist," says Peter "is well aware of the limits of her counselling, especially when it comes to handling moral concepts”. While the philosophical counsellor deals with moral attitudes, skills and concepts, the psychotherapist deals with emotions. PC can therefore effectively supplement psychotherapy and vice versa. Moreover, while philosophical counsellors shy away from labelling clients as "normal” or "abnormal”, they will refer clients who ostensibly suffer from a pathological disorder to a psychotherapist. Such clients can, as Peter puts it, clearly "not be consoled by a bit of Jean-Paul”. Finally, while the psychotherapist may be interested in locating "unconscious causes" for some or other documented and hence "readily diagnosable disease" in a "passive patient” (cf. the "medical model”), the philosophical counsellor explores, in dialogue with his client, "unexamined assumptions, values or biases that can affect thinking and behaviour in distressing ways”. However, for Peter, both the philosophical counsellor and psychotherapist acknowledge that the human will is crucial in "all human thought, emotions and actions". Both acknowledge that it is sometimes or even often necessary to underemphasize the strictly logical and objective so as to explore other dimensions, for example "the aesthetical and transcendent”. Both acknowledge that vitality can be detected and assessed in a variety of ways, and that without vitality "the human soul and heart would perish”. Both acknowledge that to question is worth much more than to give answers or to argue (cf. a “questioning approach” versus an “argumentative approach”). Both apply a variety of techniques and, like the label "psychotherapy", the label "PC" actually denotes a variety of practices, including working with individuals and with groups (though Peter actually prefers the label "Philosophical Consultation" for counselling with groups). Both the philosophical counsellor and psychotherapist are care-givers, who - because they also need to make a living - are offering their services for a fee, subject to a specific code of conduct. Both 
philosophical counsellors (or, at least some of them) and psychotherapists refer to their work as "therapy". Though the latter may use this term in a "medical" sense, for the former "therapy comes from the client's increased understanding, self-awareness, and feeling of well-being - all products of a careful exploration, in tandem with a skilled philosopher, of herself and the world around her”. Finally, the philosophical counsellor and the psychotherapist may draw from the same philosophical traditions, for example, "phenomenology and existentialism that had a telling influence on psychological practices (e.g. on the therapeutic model of Carl Rogers)”.

Mary outlines her conception of PC by comparing it with "academic" philosophy. While the philosophical counsellor draws from the "theoretical openness" of "academic" philosophy, s/he laments its lack of “relational connection”. Mary says: "Philosophy retreated into an elitist intellectualism, in the process becoming more and more removed from the everyday challenges of ordinary people simply wanting to live well”. Mary also distinguishes PC or “individual counselling” from her other philosophical practices, which may involve working with groups (e.g. a “philosopher's café”, schools, corporations or other organisations) or writing. However, she especially distinguishes PC from psychotherapy. For Mary, PC and psychotherapy may appear similar to the naked eye: "Both engage in dialogue in order to alleviate human distress". But, though PC and psychotherapy at least share this therapist-client "relational connection”, the fundamental difference between them is the psychotherapist's lack of “theoretical openness”. While the philosophical counsellor draws on any discipline, "from political theory to literature to psychology”, the psychotherapist is “...committed to psychology as 'a scientific study of mental processes and behaviour'”. This commitment has the following detrimental effects, all of which would, according to Mary, not apply to PC: (a) The psychotherapist claims the "expert" position in what becomes an hierarchical relationship with his client, thereby silencing her "voice”. The philosophical counsellor, on the other hand, does not regard himself an expert on the predicament of his client and therefore depends on her, "the one who is lost", to "lead the way". Moreover, he trusts that, by leading the way, she "will find it”; (b) The psychotherapist sees his client as a "patient" who, as such, can and should be diagnosed and treated in terms of a predetermined manual of “disorders, dysfunctions and syndromes”. This “mechanical reduction of suffering to symptoms” is unethical in so far as it “...silences those who are merely different or those who take exception to the status quo”. The philosophical counsellor, on the other hand, 
“...only wants to understand the situation or dilemma in terms that make sense to the visitor”. Moreover, her continuous criticism of any "answer” creates the "space” in which her "visitor" can “...see his predicament form many angles, and in many lights"; and (c) For the psychotherapist, emotional suffering is caused by an “underlying condition in a person's psyche - the non-physical seat of consciousness" (italics in original). But, says Mary, "if the psyche is not a physical entity, a medical model of 'diagnosis and treatment' can be of only limited and metaphorical use”. Mary concedes that these distinctions between PC and psychotherapy may not apply as rigorously to "more philosophical schools of therapy" (e.g. phenomenological or existential psychology, or, especially, Levinasian psychotherapy), and that "this question may [therefore] need more attention”. Moreover, in spite of Mary’s criticisms of psychotherapy, there is a "common feature to various forms" thereof that she finds "particularly significant”, namely a “conversational relationship": "simply talking and listening to another person” while carefully attending to him/her in "minute particulars". She says: "What psychotherapy often gets wrong [viz. theoretical openness], philosophy gets right and, conversely, what philosophy gets wrong [viz. relational connection], psychotherapy gets right. And so, I see PC as walking a line between philosophy and psychotherapy...taking the best of both [viz. theoretical openness and relational connection]...” (italics added).

While Peter and Mary seem to allow for grey areas or overlapping between PC and psychotherapy, Tsobe's demarcation is brief and decisive. According to the feedback that he received from his clients, psychotherapy is a "formal intimidating process", since it makes them feel "that they are being evaluated in accordance with certain rigid criteria to determine their 'normality' or 'abnormality””. Psychologists and psychiatrists diagnose and “treat the symptoms of illnesses and diseases, and not the people themselves”. This is done by placing clients in "specific psychological boxes [categories of illnesses]" without their input. PC, however, is an “informal process without intimidation". It does not involve evaluation "by any criteria whatsoever”, but clients "are merely guided to find their own solutions to their own problems”. For Tsobe, this makes them "visitors" and not "patients”. 


\subsection{Theme (B): Discussion}

Participants' efforts to define PC by distinguishing it from related practices resonate with a proliferation of antinomous definitions of PC (see 2.3 above). PC is being distinguished from working with groups (whether in organizational, educational or informal settings), academic and applied philosophy, and from other 'caring professions', specifically from what is often bluntly labelled as 'psychotherapy'. The latter demarcation is, as explained above, especially popular. Generally speaking, though, proponents of PC are starting to accept that: (a) The 'psychotherapy' that they enthusiastically and critically demarcate from PC, in fact only refers to therapeutic practices in so far as they incorporate the well-known 'medical model' or Freudian assumptions. The label 'psychotherapy' was used, but 'psychiatry' or 'psychoanalysis' was, in fact, meant (Ruschmann, 1998); (b) PC overlaps with a variety of psychotherapies, among which cognitive behavioural therapy (CBT), rational emotive behavioural therapy (REBT), existential phenomenological counselling (EC), narrative therapy, and logotherapy (LeBon, 2001); and (c) Just as psychologists or psychotherapists may benefit from philosophical training (Raabe, 2006), philosophical counsellors also need to take a leaf from the psychotherapist's book - not only to hone their communication/interactional skills, but also the skill to tell whether clients are "sane" (Marinoff, 2000, p. 11) enough for PC, that is, whether they are "emotionally contained" (Marinoff, 2004, p. 11). Nevertheless, all three of these contentions are still controversial. Raabe, for example, argues that, in spite of their claims to the contrary, "main-stream psychologicallybased” (Raabe, 2005, p. 521) psychotherapists do in fact "label what they see as problems in their patients” (Raabe, 2005, p. 510) in terms of predetermined categories set out in The Diagnostic and Statistical Manual of Mental Disorders (DSM) or the International Classification of Diseases (ICD). Or, at the very least, they do so in terms of Freudian diagnostic markers such as “transference, repression, resistance, denial, negativism, projection, and suppression” (Raabe, 2005, p. 510). “This,” Raabe claims, “comes from the therapists’ desire to defend and maintain their position as the expert and authority; the one who knows the patient, and the patient's mental illness, better than the patient knows herself” (Raabe, 2005, p. 520). For Raabe, distinguishing PC from psychotherapy (or, in any event, from "main-stream psychologically-based psychotherapy”) does therefore still make sense. In the same vein, Blass (1996) argues that what appears to be an overlapping between PC and cognitive psychotherapies, namely that both focus 
on 'ideas', is in fact not as it appears. For the cognitive psychotherapist 'ideas' are "psychic entities" and the focus of therapy is "the intra-psychic wiring between ideas" (Blass, 1996, p. 283). For the philosophical counsellor, on the other hand, 'ideas' are "abstract constructs” and the focus of concern is "the nature of conceptual interrelationships" (Blass, 1996, p. 283). Finally, while acknowledging that philosophical counsellors need psychological training inter alia to select or refer clients properly, Mills (1999) points out that this may not happen overnight. “Understanding potential risk factors and abnormal behavior," he warns, "takes a great deal of professional preparation, formal study, supervised experience, and extensive training in diagnostics, assessment, and clinical intervention” (Mills, 1999, p.152).

\subsection{Theme (C): Engaging with the other methodically}

All three participants seem to identify PC with techniques and procedures. That is, their experience of PC seems to involve the application of some or other approach or methodology, though it may not be rigidly defined or applied.

For Peter dialogue is the mainstay of the approach that he follows in PC. He prefers the term “dialogical partnership” so as to emphasize the non-hierarchical nature of the counsellor-client relationship. The counsellor is not the expert with all the answers. Instead, for Peter, "counselling is in the first place about the exploration of questions [in a Socratic style, which assumes that] the answers are in [the client]. I am only trying to facilitate the [finding thereof]". These questions may include a wide variety of issues, which he describes in terms of overlapping categories such as socio-political, ethical, existential, emotional, spiritual and sexual. A session may therefore include the discussion of inter alia meaning-of-life issues, value conflicts (moral dilemmas), world-views, self-appraisals, personal crises, career guidance, etc., especially in so far as these matters relate to "confused or obstructed" thinking (i.e. conceptualisations or reasoning). “Through a series of dialogues,” explains Peter, “the counsellor helps the client come to an awareness of hidden biases, unspoken assumptions, and conflicting values that may be

preventing an inquiry into alternative perspectives that could help to ease the problem”. Clients may also see him "simply to enrich and intellectually stimulate themselves", though a session will exclude "intellectualisations". It will also exclude "lecturing”, though the counsellor may 
teach his client the very skills that he applies in counselling, thus empowering her to prevent similar problems in future. These skills may include: (a) the ability to think (self-)critically (to “spot inconsistencies, contradictions, and other problems in reasoning”) and creatively (to "think outside the box"); (b) the ability to analyse (to "separate large masses of information in manageable pieces”) and synthesise (to "put them all back together again”); and (c) the skill of “active listening” (attentive and empathetic listening). The latter skill is important right from the first session when the counsellor needs to build a relationship of both familiarity ("vertroudheidsverhouding”) and trust ("vertrouensverhouding”) with his client. Peter does so by, as he puts it, “moving from his dialogical partner's broadest contours (e.g. background, personal history) via closer lines (marriage, relationships, children, family, as well as career), to personality, values and aspirations”. This allows the client to look at her life and predicament “from a distance”. A variety of techniques and aids may come into play, for example, assessment with a "vitality meter", the use of a diary through which the client may develop "the confidence to assert herself creatively in word and image", and what Peter calls "self-exploration through metaphors”. For this he finds recent developments in philosophical hermeneutics useful, especially Ricoeur's use of Jakobsen's work, which gives rise to an understanding of the world (including oneself) as a work of art, that is, "an ensemble of created and constantly re-created meaning and significance”. Finally, Peter describes his counselling as "client-centred and openended in nature, one which does not manipulate the client's thinking so as to bring her to... the 'Truth'. The counsellor's intention is to help his client reach any reasonable and morally permissible goal the client has set for herself”.

At first it seems as if, for Mary, PC does not have a method at all. She says: "PC is not characterised by techniques or theories, but by a commitment to consider the client or guest's life situation as unique and significant”. In fact, as a Levinasian counsellor, Mary deliberately steers away from the idea that PC involves the application of theory. Instead, for her, PC is "good practice” or "the practice of the good" that "transcends contemplation”: “...a practice of ethics which transcends and is prior to any ethical code or principles; engaged dialogue with and for the other, with no prior convictions, ambitions or theoretical ground...”. Yet, in spite of this apparent disavowal of theoria, the following approach or what she calls "guiding principles" can be delineated from her account of PC. The counsellor's "first order of business" is to "attend to" her 
guest and make her feel "at home" or "welcome”. This "non-violent, non-coercive face-to-face co-presence” creates the space in which the counsellor can engage in a focussed dialogue with her guest, that is, can address his predicament with him "side-by-side". Here the guest needs to take the lead, since "it is his world that matters". "There is [therefore] a kind of inversion in our situation,” says Mary, “one which confronts my mastery and sufficiency”. The predicament in question may include any difficulty: from existential problems or academic problems (e.g. the need to "just talk philosophy, perhaps discuss particular thinkers or texts”) to a need for "selfunderstanding” or "inner stability" (in case of which "problem” and "person” would, in a sense, coincide). Guests are encouraged to find answers to their own questions, that is, “...to discover and develop their own guiding wisdom". However, PC may also involve "pedagogical” inputs from the counsellor in so far as she may teach her guest to formulate his questions properly and to avoid "abstract, empty intellectualisations”. PC thus involves description (i.e. giving a voice to the guest's experience or predicament; clarifying his "perceptions, assumptions, beliefs and reasons”), interpretation (i.e. considering the significance, relevance or meaning of questions for the guest; dealing with his "values and worldview”) and critical investigation or analysis. To paraphrase Mary (by way of Levinas): "We try to make sense and we test our beliefs and assumptions. We say 'Do you know what I mean?' and 'Is that right?’”. Or, as Mary also puts it: “The PC relationship combines skills of the mind (questioning and reasoning) and the experience of dialogue (speaking and listening to each other with care and attention)”. PC also requires the application of a number of other (overlapping) skills, among which "learning to recognize and follow the right question"; "letting one question [or idea] lead to others"; "moving back and forth” between "goal-oriented 'where-do-I-walk-from-here?"” questions and "more open and fundamental questing after wisdom”; drawing on the "traditions of philosophy”; providing “alternate perspectives” and, finally, remaining “sceptical (or questioning) about any truth or 'answer' that presents itself”. “This way of inquiring never really stops,” says Mary, “I don’t know where we're going...I trust that by speaking [my guest] will learn to speak, to find her voice....and so come to live with more confidence and clarity”. For Mary this open-endedness and “trust” also applies to her own "speaking” about PC. She says: "Even as I try to give you some idea here of what PC is all about and how it proceeds, I can assure at the same time that it is constantly reinvented or reimagined...My bottom line is very Socratic. I'm like the guy (quoting 
John Caputo) who keeps saying, in the midst of whatever's happening, 'what's happening?'...I am appalled by any attempt to nail [PC] down to 'this alone, and not that'”.

In contrast to both Peter's and Mary’s approach, Tsobe’s PC methodology can be summarised in discrete steps: (a) The visitor receives a list of words that each describe an emotional state; (b) The visitor chooses the five words that best apply to her "state" or "situation" and then decides on only one word; (c) The visitor now formulates a "vision (dream) of how she would like to be" and a "simple mission (how to get there)"; (d) She then engages in an "ONPO-analysis": (i) “Obstacle”: exactly how does her present situation prevent her from reaching her dream?; (ii) "Negatives": what are the negative implications of her current "state" or predicament?; (iii) "Positives": what will the positive implications be if these "negatives" can be eliminated?; and (iv) "Outcomes": what will the outcomes be, generally speaking, if she overcomes her current predicament?; and (e) The visitor compiles "a personal action programme” in view of this analysis: "What are the solution(s)?; How will one arrive at the solutions?; Who will do what in these activities?; When will this happen (exact time framework) and how will the programme be evaluated?". Throughout this process, says Tsobe, he will, as counsellor, merely "suggest [through Socratic questioning] instead of tell or advise”. The rest is up to the visitor herself.

\subsection{Theme (C): Discussion}

To varying degrees the counselling approaches or methodologies of all three participants involve the following: (a) building a rapport with the client; (b) engaging in dialogue with the client; (c) respecting and enhancing the client's autonomy; (d) acknowledging the client's equal authority; (e) teaching the client; (f) descriptive interpretation, critique, and creative innovation of the views of the self and world of both client and counsellor; (g) a quest for equilibrium; (h) open-endedness; (i) being person-oriented; (j) applying philosophical skills; (k) applying philosophical theory (i.e. drawing from philosophical texts); (l) Socratic questioning or prompting; and (m) scepticism vis-à-vis the assumption that 'the truth' can be finally or conclusively established. However, the participants also differ in this regard. For example, Tsobe's approach could perhaps also be interpreted as end-point-oriented (and not open-ended), or problem-oriented (and not person-oriented). He also does not seem to entertain the notion that 
PC could sometimes merely comprise an academic discussion of some or other philosophical issue or text, while both Peter and Mary do. Mary, again, toys with the notion (by way of Levinas) that PC has no methodology, while Peter and certainly Tsobe do not seem to question the fact that it has. Nevertheless, these overlapping and in some instances contradicting techniques or procedures resonate widely with philosophical counsellors (cf. Raabe, 2001). Yet, they are all controversial. For example, Jenkins (2002) pointed out (by way of Foucault) that pursuing the autonomy of the client (see (c) above) would be misleading (and hence unethical) if 'autonomous' is assumed to mean 'radically separate or completely free from any social domination'. Jopling (1996), again, cautioned philosophical counsellors against being overly sceptical with regard to establishing the ‘truth’ (see (m) above), also and especially with regard to the 'selves' of clients. In fact, Jopling claims it is the responsibility of philosophical counsellors, as philosophers, to assist clients in avoiding "falsity, error, deception, illusion, wishful thinking, and logical fallacy" on their way to a "truth-oriented self-understanding" (Jopling, 1996, p. 308; cf. also Paden, 1998). And, to list a third and final example of the controversy around the techniques or procedures listed above, Svare questions the 'equal authority' of the client (see (d) above), by reminding us that, in the dialogical relationship between philosophical counsellor and client, one of the partners, the counsellor, “...occupies the role of a professional...” (Svare, 2002, p. 248). There therefore seems to be no sufficiently integrated or generally acceptable version of PC's methodology. This seems to give substance to Mary’s denial (or, at least, prima facie denial) of such a methodology (cf. also Achenbach's method “beyond method” (Schuster, 1999, p. 38), and Pollastri’s (2006, p.107) “improvisation”). Though as Jongsma (1995) rightly noted, a clearly defined methodology would give PC a distinct identity and, as such respectability in the eyes of potential clients, practitioners, and professionals who might want to refer their clients to philosophical counsellors. Tsobe's discretely defined "ONPO-analysis" (see above) would seemingly serve this purpose significantly better than the suggestions of both Peter and Mary in this regard. As such, Tsobe's step-by-step approach resonates with Prins-Bakker's (1995), Marinoff's (2000), and Raabe's (2001) proposals (see 2.1 and 2.2 above). But be that as it may, perhaps the techniques and procedures of PC can, in spite of their complex variety, be summarised in terms of a slightly enhanced understanding of two categories introduced by Mary (see 4.3 above), namely 'relational connection' and 'theoretical openness'. The former involves all procedures 
predominantly aimed at containing the client. Generally speaking, these are the procedures one would expect in a psychotherapeutic session, especially of the client-centred variety. They are the techniques involved in the “...creation of a supportive, nonthreatening relationship within which the client feels comfortable enough to examine his or her most basic assumptions...” (Paden, 1998, p. 13). The latter category, namely 'theoretical openness', constitutes the 'philosophical' component of PC, that is it involves the application of both philosophical skills and philosophical theory. These are the procedures of philosophers qua philosophers, “...those standard techniques of description, analysis, self-reflection and argument ...” (Paden, 1998, p. 13), which are most fully developed within and with reference to the history of philosophical reflection. However, they could also be expected in psychotherapeutic sessions, especially in so far as it is assumed that ways of thinking (i.e. reasoning or conceiving) significantly determine, influence or condition ways of being (i.e. acting, feeling, relating or coping).

\subsection{Theme (D): Caring for the other}

It seems that for all three participants the experience of PC involves caring for the other. This care is believed to be: (a) fundamental to life in general and PC in particular; (b) comprehensive, inter alia in the sense that it is not only aimed at personal problems, but also the socio-political milieu of clients; and (c) primarily aimed at local needs.

That care is, for Peter, fundamental to life in general and PC in particular, becomes apparent in view of the strongly worded phrases that he uses to express his views in this regard. He says: "My experience [of PC] is throughout that the meaning of life in this regard is to make a [constructive] difference to the lives of people” (italics added). Though he experiences PC as "self-enriching”, he stresses the fact that PC is "primarily for the benefit of the client”. Or, as he also puts it, the foundation of PC is constituted by the "morally permissible", which, at bottom, concerns care for the other. Philosophical counsellors therefore not only need to "declare their commitment to render a professional service", but they also need to "pledge to conduct an ethical practice”. As such PC has a comprehensive scope, that is, it addresses the conceptions of clients

on all matters including their socio-political well-being. Peter says: “The strong 'democratisation' of societies during the past half-century is essentially a creation of the ancient 
Greek philosophers". For Peter these societies include local societies, all of which comprise "the Southern African set-up”. His contribution includes a description of how he contributed to the “democratisation” of this "set-up” through founding the South African Philosopher Consultants Association (SAPCA). He did so in collaboration with other "concerned" philosophical counsellors, all of whom realize that, while they aim to render a professional service, their South African clients may not always be in a position to pay for services rendered.

For Mary, following Levinas, PC fundamentally involves care in so far as it originates in the "loving relationship" in which the "self” stands with "the Other” "before knowledge”. As such, the "I" finds him-/herself "in the face of the Other" as "always already" (and thus unavoidably) responsible for "the Other”. Being an "I” pre-reflectively constitutes “being-for-the-other”. Or, as Mary also puts it: “...before I [as philosophical counsellor] intend or choose to (before I intend or choose anything), I find myself already involved with this other [my client] who faces me, already saying yes, here I am, come in" (italics in original). In this sense we may, according to her, regard philosophy (with Levinas) as first "the wisdom of love at the service of love" before being "the love of wisdom”, and we may “...conceive of philosophical counseling as, from the first, a practice of ethics and the wisdom of love". The counsellor "honours" this pre-reflective loving or caring relationship between counsellor and "guest” by "maintaining” her. This involves not only "making her feel welcome or at home", but also addressing her "question" or “predicament” by "talking it through" with her, that is, through a "dialogue” or "discourse” that neither "violates" the "guest”, nor the counsellor. For Mary "care”, as a fundamental constituent of PC, does therefore not only include attending to the other or client, but also to the self or counsellor. This is the first sense in which the care in question could be regarded as comprehensive. The second sense has to do with what Mary indicates as the "transcendence" or "infinite otherness" of the other, which by implication makes her responsibility towards her clients “inexhaustible” and unpredictable. Mary says: “There’s no saying in advance who we'll be able to work with (though it won't be everyone), what exactly they will want from us (other than everything), or whether or not we'll be able to offer the right bit in the right way in the right moment... Fear and trembling always come with the territory”. The third sense in which the care that is PC is, for Mary, a comprehensive care, relates to the fact that the philosophical counsellor not only addresses the personal problems of clients, but also the problems of their respective 
communities. Differently put, a problem is not addressed in isolation from its socio-political ecology. For Mary the "trouble” that “...the stranger, the widow and the orphan...the nearest one who calls me to love brings" is therefore, strictly speaking, never 'personal'. "In my view," she says, PC “...also finds meaning in/is concerned with social and political relations, ethics, freedom, justice, will and desire...” - a view that she illustrated well by her efforts to right sociopolitical wrongs locally. Her contribution includes a description of how she and her husband assisted the anti-apartheid movement in the struggle years by setting up "safe-houses" which allowed the infiltration back into South Africa of senior leaders of the ANC.

For Tsobe PC is fundamentally about care for the other in so far as it, if properly conducted, exemplifies Ubuntu. For him, Ubuntu “intensely” encapsulates the closely related values of humanness, caring, sharing, respect and compassion. This means "loving and accepting” visitors, "listening" to them and "empathising or sympathising" with them. However, as comprehensive care, Ubuntu also means being "intolerant" towards the "violence, aggression, social misbehaviour and injustices” that his visitors may have to endure. Ubuntu, says Tsobe, “encompasses everything the human mind can experience or think of”. Unjust practices often leads to loneliness and depression, which Tsobe addresses locally by organising bus trips and friendship clubs at a nominal fee for participants. While this may be a way to canvass clients, for him it is, at bottom, a way of (simply) caring for others and of providing after care for existing clients. That this care should at least commence locally, is of special importance to Tsobe, since, according to the Ubuntu world view, "sharing starts at home” - hence also his preference, as an African, to communicate "values that are inherently similar to those of people in all continents" specifically through a local world view, that is, a world view "peculiar to Africa”.

\subsection{Theme (D): Discussion}

That the word 'care' is most frequently used by philosophical counsellors to describe their practice, testifies to the fact that it is being experienced as fundamental to PC. That is, it is experienced as an essential or necessary, if not perhaps sufficient, element of PC. Norman (1995, p. 50), for example, primarily describes the philosophical counsellor - counselee relationship as “...caring rather than confrontational”. And with reference to a number of philosophical 
narratives and counsellors Schuster simply defines PC as a “...practice of care, i.e. care of the self and its world” (Schuster, 1997b, p. 114; cf. also Schuster, 1999, 2006). This definition also echoes the participants' assumption that the care in question is and needs to be comprehensive (cf. also Lahav, 2006; Marinoff, 1998). However, it seems as if, for the participants, the 'comprehensive care' of PC may also include getting directly involved in the improvement of the socio-political circumstances of counselees (by, for example, participating in community projects), and not just indirectly (by, for example, addressing thought patterns that may have socio-political implications). All three participants included in their stories of PC descriptions of ways in which they got 'directly' involved in the improvement of the socio-political predicaments of clients, and Tsobe added in so many words that the care that is Ubuntu (read: proper PC) demands such involvement. If this understanding of the participants' contributions is correct, then one may well wonder whether their conception of the scope of PC is unique to South African participants, since it is not, in so far as could be established, being echoed by their colleagues abroad. One may also hypothesize about a significant correlation between this seemingly unique understanding of the scope of PC and South Africa's rich and recent history of political activism. The same applies to the participants' apparent assumption that the care in question also - if not primarily - needs to be provided locally. Whatever the case may be, all three participants would seemingly affirm Mills's (1999) contention that, if care is indeed the mainstay of PC, then philosophical counsellors should not stray from an ethical critique of their practice. Such critique would, as Epright (2003, p. 22) rightly argues, “expand PC into the public sphere” where it belongs. After all, it purports to serve or care for the public at large and to do so professionally (Shipley \& Leal, 2002).

\section{Towards a conclusion}

So what is PC? Or, more precisely, what is PC as practised in South Africa? The heading 'towards a conclusion' (instead of simply ‘conclusion') here indicates that the concluding section of this deliberation does not pretend to be a final, all-inclusive summary of the participants' stories of PC (read: the researcher's story of their stories). This is not only due to the fact that an interpretation thereof at any specific point in time confronts the researcher with a bewildering variety of assumptions and implications. It rather and also speaks to the fact that he is 
experiencing - much like Peter (see 4.3 above) - the re-telling of the participants' stories (read: the re-telling of his own story of their stories) as a process within which PC 'unfolds' or 'reveals' itself to him continuously. He is, in short, experiencing the diachronic proliferation of the meaning of PC. Moreover, the phrase ‘towards a conclusion’ also acknowledges the synchronic proliferation of this meaning. That is, it acknowledges the fact that: (a) other interpreters may infer different themes from the participants’ PC stories (i.e. may tell different stories of their stories); (b) in so far as different interpreters operate within different horizons of understanding, they would, strictly speaking, never infer quite the same themes, even if it appears to be the case; and (c) each participant's story involves each of the identified themes in a unique way. These themes do therefore not constitute monolithic similarities between stories.

A minimal definition of PC, with which all the participants may agree, reads as follows:

'PC involves a trained philosopher helping an individual to deal with his/her problem'.

However, the inferred themes, as discussed above, require that this minimal definition at least be revised to read as follows:

'PC embodies the process wherein I, Peter/Mary/Tsobe, professionally care for your self and world (and thereby for my self and world) by applying my training in philosophical skills and theory to address your problem (or by empowering you to address your own problem through teaching you the self-same skills and theory). I can address your problem only in so far as it involves sane, yet confused or obstructed thinking (i.e. reasoning or conceiving), and not in so far as it involves physiological or neuropsychiatric dysfunction. I do so (self-)critically and creatively in a dialogical partnership with you, while constantly securing that you are comfortable in my presence and I in yours, thereby acknowledging our inter-dependence as discussants and as 'I's', that is, as autonomous, yet vulnerable unique selves. Through our probing and prompting questions we continually co-create a space within which both of us may find and keep finding our own ways of dealing with the problem in question, whether it be existential or academic.' 
This admittedly cumbersome definition goes a long way in 'zip filing' the assumptions, process, subject, subject matter, methodology, tools and techniques of PC, as well as the nature of its scope of practice, potential clients, its counsellor-client relationship, its relations with psychology and psychiatry, and its foreseeable effects. Yet, in spite of its density, it falls selfconsciously short of the participants' PC stories as recounted thematically by the researcher. For example, it barely does justice to Mary’s Levinasian understanding of PC 'before knowledge', or to Tsobe's highly structured and perhaps predominantly end-point and problem oriented approach, or to Peter’s detailed demarcation between PC and psychotherapy.

This brings us to the second question posed at the outset of this report: Does a uniquely South African brand of PC exist, that is, an understanding of PC that cannot be found in the current predominantly 'First World' or 'Northern' (European and North American) literature on the subject? Do the participants' stories entail peculiarities not to be found in the variety of PC stories from other parts of the world? As it stands, our 'conclusive' definition of PC resonates with the sentiments of philosophical counsellors not practising in South Africa. Not all of them would wholeheartedly agree with it though, but each would at least be able to find some overlapping with his/her own conception of PC. However, for the sake of this discussion, the above definition deliberately all but ignored three important elements in the participants' PC stories, namely: (a) that the care that is PC may include getting 'directly' involved in the betterment of the socio-political circumstances of clients, that is, in ways other than merely addressing their thinking (conceptions or arguments) in this regard; (b) that the care that is PC should also, if not primarily, be focussed on local predicaments (cf. the 'charity begins at home' principle); and, last, but not least, (c) that the care that is PC may be profoundly expressed in a uniquely African narrative called 'Ubuntu'. In so far as the researcher could establish, none of these elements can be found in the existing non-South African literature on PC. As such they might well be seen as constituting a distinctly South African contribution to the PC debate - an own voice and a new beginning: a uniquely 'Southern' impetus to reimagine and transcend 'Northern' notions.

However, the findings of this study may not only stimulate a 'North-South' debate on the nature of PC. It may also facilitate a dialogue between philosophical counsellors and their colleagues in 
related lines of work, including 'academic' philosophers, 'applied' philosophers, and other 'skilled helpers' in 'caring professions'. The themes identified in this study may especially foster mutual understanding and cooperation between philosophical counsellors and mental health professionals like psychologists and psychiatrists, thus creating an ecology wherein philosophers acquire psychotherapeutic skills and psychologists or psychiatrists enrol for philosophy programmes. That is - to paraphrase the Ubuntu aphorism (cf. Louw, n.d.) - an ecology wherein philosophers become counsellors through psychologists and psychiatrists, and wherein psychologists and psychiatrists become psychotherapists through philosophers.

\section{umuntu ngumuntu ngabantu}

'a person is a person through other persons' 


\section{References}

Achenbach, G.B. (1995). Philosophy, philosophical practice, and psychotherapy. In R. Lahav \& M.d.V. Tillmans (Eds.), Essays on philosophical counseling (pp. 61-74). New York: University Press of America.

Blass, R.B. (1996). The ‘person’ in philosophical counselling vs. psychotherapy and the possibility of interchange between the fields. Journal of Applied Philosophy, 13(3), 279295.

Corey, G. (2001). Theory and practice of counseling and psychotherapy. Belmont, CA: Wadsworth/Thomson Learning.

De Botton, A. (1997). How Proust can change your life. London: Picador.

Dias, J.H. (2006). René Descartes, philosophical counsellor of Elizabeth. In J.Barrientos Rastrojo (Ed.), Philosophers as philosophical practitioners (vol.I). (pp.171-184). Seville: X-XI Association.

Doan, R.E. (1997). Narrative therapy, postmodernism, social constructionism and constructivism: Discussions and distinctions. Transactional Analysis Journal, 27(2), 129133.

Douglas, H. (2005). The idea of a possibility. European Journal of Psychotherapy, Counselling and Health, 7(1-2), 89-95.

Douglas, H. (2008). Levinas in practice: Face to face and side by side. Philosophical Practice: Journal of the American Philosophical Practitioners Association 3(1), 226-234.

Ellenbogen, S. (2006). Wittgenstein and philosophical counselling. In J.Barrientos Rastrojo (Ed.), Philosophers as philosophical practitioners (vol. II) (pp.103-110). Seville: X-XI Association.

Epright, M.C. (2003). Philosophical counselling: A paradigm for clinical medical ethics?. Philosophy in the Contemporary World, 10(2), 17-22.

Fleming, J. (2006). Philosophical counselling and Chuang Tzu’s philosophy of love. In J.Barrientos Rastrojo (Ed.), Philosophers as philosophical practitioners (vol.I). (pp.1120). Seville: X-XI Association.

Fourie, D.P. (1996). The research/practice gap in psychotherapy: From discovering reality to 
making sense. Journal of Contemporary Psychotherapy, 26(1), 7-22.

Gutknecht, T. (2006). Toward philosophy of the practice of philosophy. An invitation to philosophical dialogue among practitioners of philosophy about the nature of their work. In J.Barrientos Rastrojo (Ed.), Philosophical practice: From theory to practice (pp. 8991). Seville: X-XI Association.

Hadot, P. (1995). Philosophy as a way of life. Oxford: Blackwell.

Jenkins, F. (2002). Philosophical counselling as care of the self: Notes on Foucault's genealogy of ethics. In H. Herrestad, A. Holt, \& H. Svare (Eds.), Philosophy in society (pp. 287296). Oslo: Unipub.

Jongsma, I. (1995). Philosophical counseling in Holland: History and open issues. In R. Lahav \& M.d.V. Tillmans (Eds.), Essays on philosophical counseling (pp. 25-34). New York: University Press of America.

Jopling, D.A. (1996). Philosophical counselling, truth and self-interpretation. Journal of Applied Philosophy, 13(3), 297-310.

Jopling, D.A. (2000). Self-knowledge and the self. New York: Routledge.

Kelly, K. (1999). Hermeneutics in action: empathy and interpretation in qualitative research. In M. Terre Blanche \& K. Durrheim (Eds.), Research in practice: Applied methods for the social sciences (pp. 398 - 420). Cape Town: University of Cape Town Press.

Kessels, J. (1997). The Socratic Dialogue as a method of organizational learning. In W. Van der Vlist (Ed.). Perspectives in philosophical practice. (pp. 45-66). Leusden: Vereniging voor Filosofische Praktijk.

Knapp, S., \& Tjeltveit, A.C. (2005). A review and critical analysis of philosophical counseling. Professional Psychology: Research and Practice, 36(5), 558-565.

Kvale, S. (1983). The qualitative research interview: A phenomenological and hermeneutical mode of understanding. Journal of Phenomenological Psychology, 14(2), 171 - 195.

Lahav, R. (1995). A conceptual framework for philosophical counseling: Worldview interpretation. In R. Lahav \& M.d.V. Tillmans (Eds.), Essays on philosophical counseling (pp. 3-24). New York: University Press of America.

Lahav, R. (1996). What is philosophical in philosophical counselling?. Journal of Applied Philosophy 13(3), 259-278.

Lahav, R. (2006). Small philosophical practice and grand philosophical practice. In J.Barrientos 
Rastrojo (Ed.), Philosophical practice: From theory to practice (pp. 93-96). Seville: XXI Association.

Lahav, R., \& Tillmans, M.d.V. (1995). Introduction. In R. Lahav \& M.d.V. Tillmans (Eds.), Essays on philosophical counseling (pp. ix-xxv). New York: University Press of America.

LeBon, T. (2001). Wise therapy. London and New York: Continuum.

Liamputtong, P., \& Ezzy, D. (2005). Qualitative research methods ( $2^{\text {nd }}$ ed.). Oxford: Oxford University Press.

Lifschitz, S., \& Oosthuizen, C. (2001). Discovering agapé: forming and re-forming a healing community. In M. Seedat, N. Duncan, \& S. Lazarus (Eds.), Theory, method and practice in community psychology. South African and other perspectives (pp.107-131). Cape Town: Oxford University Press.

Lipman, M. (1988). Philosophy goes to school. Philadelphia: Temple University Press.

Louw, D.J. (n.d.). Ubuntu and the challenges of multiculturalism in post-apartheid South Africa. Retrieved March 9, 2009, from the Unitwin Student Network web site: http://www.phys.uu.nl/ unitwin/ubuntu.html

Louw, D.J. (1996). Decolonization as postmodernization. In J.G. Malherbe (Ed.), Decolonizing the mind (pp. 67-73). UNISA, Pretoria: Dept. of Philosophy.

Louw, D.J. (2004, June/July). Philosophical counselling. Paper presented at the Conference of the World Council for Psychotherapy (African Chapter), University of Limpopo, Sovenga/Polokwane, South Africa.

Louw, T. (1999, January). Filosofiese berading: Goeie ou wyn in nuwe vate?. Paper presented at the Annual Conference of the Philosophical Society of Southern Africa (PSSA). Free State University, Bloemfontein, South Africa. Unpublished.

Louw, T. (2001, November 27). 2001 Report. Message posted to http://groups.yahoo.com/group/SAfiloskonsult/

Màdera, R., \& Tarca, L.V. (2008). Philosophy as life path. An Introduction to philosophical practices. Milan: IPOC.

Marinoff, L. (1998). What philosophical counselling can’t do. Philosophy in the Contemporary World 5(4), 33-41.

Marinoff, L. (2000). Plato, not Prozac!: Applying eternal wisdom to everyday problems. New 
York: Quill.

Marinoff, L. (2004). The big questions. How philosophy can change your life. London: Bloomsbury.

Mijuskovic, B. (1995). Some reflections on philosophical counseling and psychotherapy. In R.

Lahav \& M.d.V. Tillmans (Eds.), Essays on philosophical counseling (pp. 101-120). New York: University Press of America.

Mills, J. (1999). Ethical considerations and training recommendations for philosophical counselling. International Journal of Applied Philosophy 13(2), 149-164.

Norman, B. (1995). Philosophical counseling: The arts of ecological relationship and interpretation. In R. Lahav \& M.d.V. Tillmans (Eds.), Essays on philosophical counseling (pp. 49-58). New York: University Press of America.

Paden, R. (1998). Defining philosophical counseling. International Journal of Applied Philosophy, 12(1),1-17.

Phillips, C. (2001). Socrates café: A fresh taste of philosophy. New York: W.W. Norton \& Co. Philosophical Consultancy. (n.d.). Retrieved March 6, 2009, from http://en.wikipedia.org/wiki/Philosophical_Consultancy

Pollastri, N. (2006). Improvisation. A “method” of philosophical consultation. In J.Barrientos Rastrojo (Ed.), Philosophical practice: From theory to practice (pp. 107-115). Seville: X-XI Association.

Prins, A. (1997).Towards a companion to philosophical counselling. In W. Van der Vlist (Ed.). Perspectives in philosophical practice. (pp. 87-90). Leusden: Vereniging voor Filosofische Praktijk.

Prins-Bakker, A. (1995). Philosophy in marriage counseling. In R. Lahav \& M.d.V. Tillmans (Eds.), Essays on philosophical counseling (pp. 135-151). New York: University Press of America.

Raabe, P.B. (2001). Philosophical counseling: Theory and practice. London: Praeger.

Raabe, P.B. (2005). Reinterpreting psychiatric diagnoses. Janus Head, 8(2), 509-521.

Raabe, P.B. (2006). From philosophical counselling to philosophy for counsellors. In J.Barrientos Rastrojo (Ed.), Philosophical practice: From theory to practice (pp. 133141). Seville: X-XI Association.

Ruschmann, E. (1998). Foundations of philosophical counselling. Inquiry: Critical thinking 
across the disciplines, 17(3), 21-35.

Robbins, S. (2006). Christian philosophical practice and way of life. In J.Barrientos Rastrojo (Ed.), Philosophers as philosophical practitioners (vol. I) (pp.127-136). Seville: X-XI Association.

Segal, S. (1995). Meaning crisis: Philosophical counseling and psychotherapy. In R. Lahav \& M.d.V. Tillmans (Eds.), Essays on philosophical counseling (pp. 101-120). New York: University Press of America.

Schuster, S.C. (1997a). Sartre's words: A paradigm for self-description in philosophical counseling. In W. Van der Vlist (Ed.). Perspectives in philosophical practice. (pp. 2021). Leusden: Vereniging voor Filosofische Praktijk.

Schuster, S.C. (1997b). Philosophical narratives and philosophical counselling. Journal of the Society for Existential Analysis, 8(2), 108-127.

Schuster, S.C. (1998). On philosophical self-diagnosis and self-help: A clarification of the nonclinical practice of philosophical counselling. International Journal of Applied Philosophy, 12(1), 37-50.

Schuster, S.C. (1999). Philosophy practice: An alternative to counseling and psychotherapy. Westport: Praeger.

Schuster, S.C. (2002). In times of war and terror: Philosophical counselling as an alternative to treatment of post-traumatic stress disorder. Canadian Journal of Community Mental Health, 21(2), 79-90.

Schuster, S.C. (2006). Philosophical counselling and the I and Thou: A philosophical autobiographical narrative. In J.Barrientos Rastrojo (Ed.), Philosophers as philosophical practitioners (vol. II) (pp.91-99). Seville: X-XI Association.

Shipley, P., \& Leal, F. (2002). Is practical philosophy for private profit or public good?: A critical view of the practical turn in contemporary philosophy. Philosophy in the Contemporary World 9(1), 1-9.

Sivil, R.C. (2009). On the nature of philosophical counseling. Paper presented at the annual conference of the Philosophical Society of Southern Africa (PSSA). University of Fort Hare, Hogsback, South Africa. Unpublished.

Svare, H. (2002). The philosophy of dialogue. In H. Herrestad, A. Holt, \& H. Svare (Eds.), Philosophy in society (pp. 243-250). Oslo: Unipub. 
Svare, H. (2006). Kant and philosophical counseling. In J.Barrientos Rastrojo (Ed.), Philosophers as philosophical practitioners (vol. II) (pp.11-17). Seville: X-XI Association.

Swart, N. \& Wiehahn, G. (1979). Interpersonal manoeuvres and behaviour change. Pretoria and Cape Town: Academica.

Van der Merwe, J.C. (2001). Why there is no need to defend philosophy as a way of life in the West. Tydskrif vir Christelike Wetenskap, 37(Spesiale Uitgawe), 117-131.

Van Hooft, S. (2002). Philosophy and the care of the self: A literature survey. Sophia 41(1), 89134.

Von Morstein, P. (n.d.). Philosophical counselling. Retrieved March 7, 2009, from Canadian Society for Philosophical Practice web site:

http://www.philosophicalpractice.ca/Morstein-on-PC.html

Walsh, R.D. (2005). Philosophical counselling practice. Janus Head, 8(2), 497-508. 